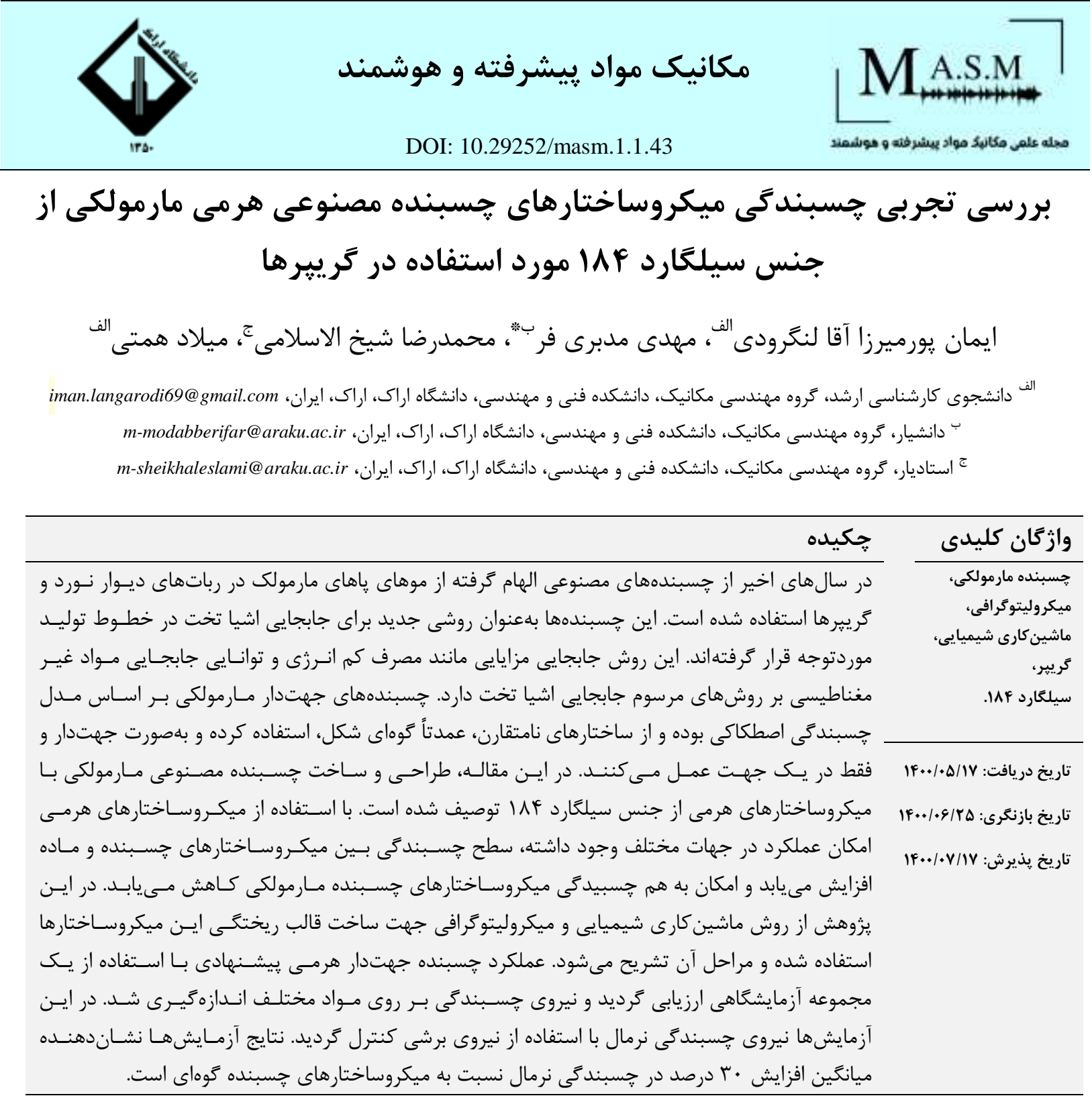

\title{
Experimental Investigation of Adhesion of Synthetic Pyramid Shape Gecko-like Micro-structured Adhesive for Grippers Made of Silgard 184
}

\section{Iman Pourmirzaagha Langroodi a, Mehdi Modabberifar ${ }^{a^{*}}$, Mohammad reza Sheykholeslamia, Milad Hemmatia}

${ }^{a}$ Department Mechanical Engineering, Arak University, Arak, 3848177584, Iran

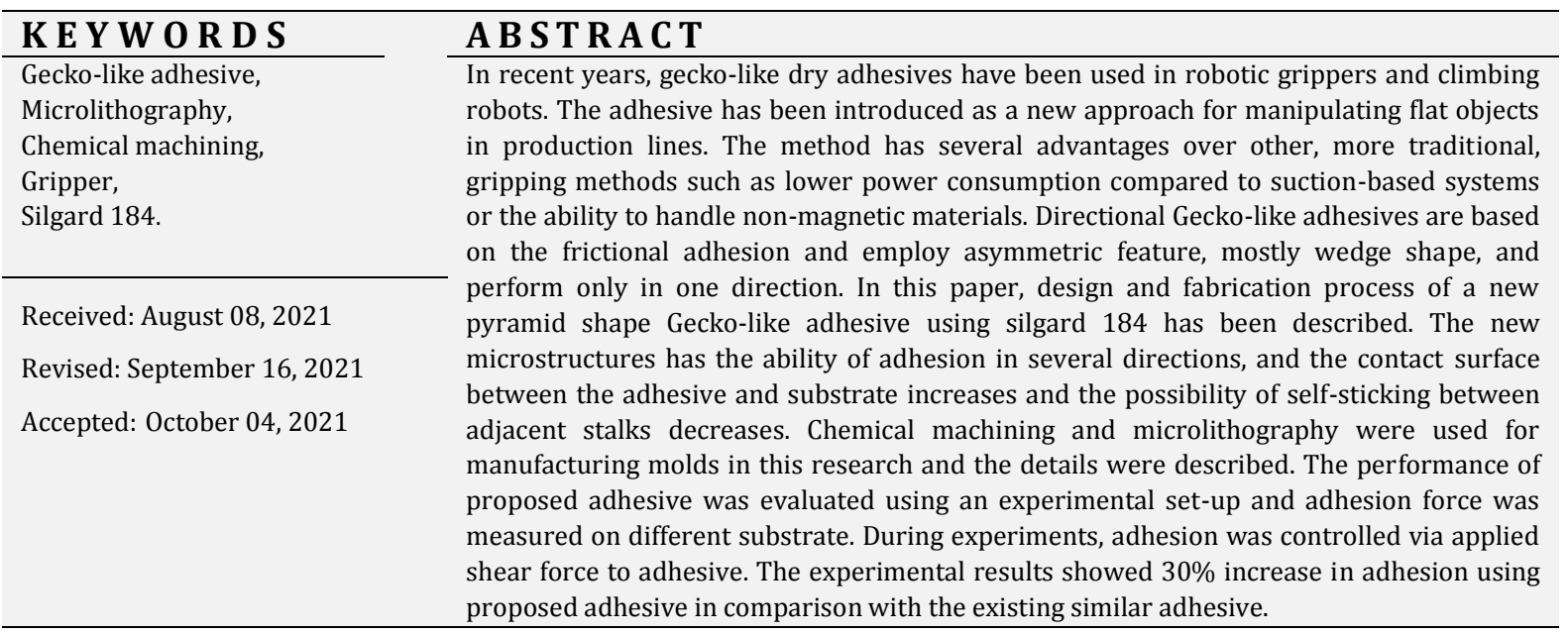




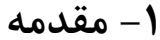

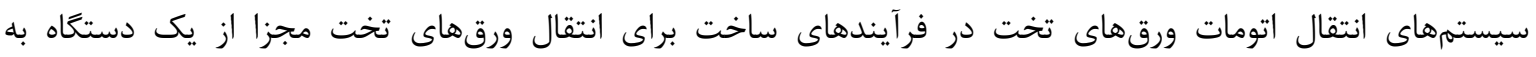

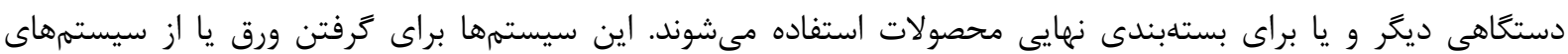

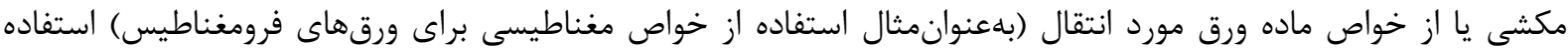

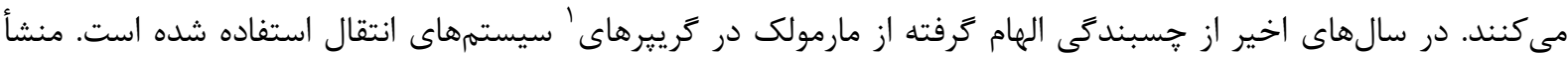

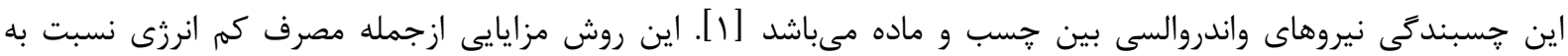

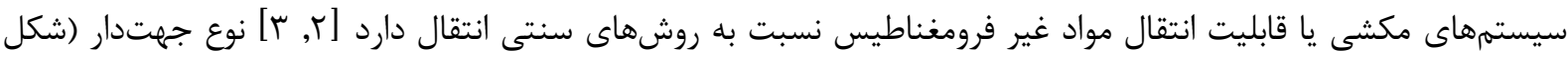

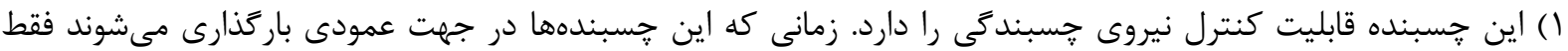

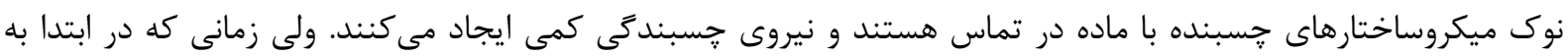

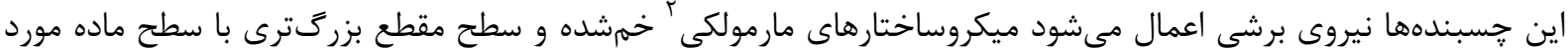

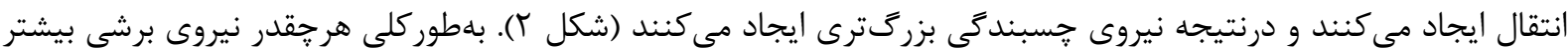

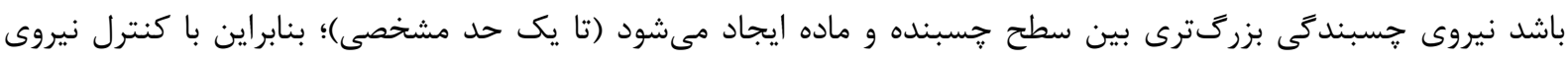

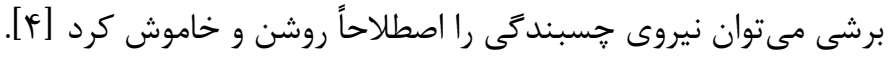

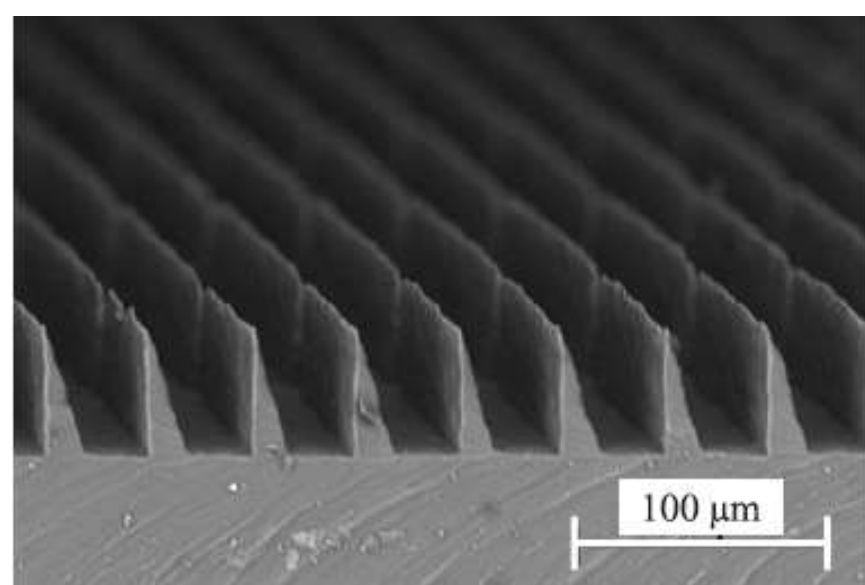

شكل ا يك نمونه جسبنده مصنوعى مارمولكى جهتدار [r]

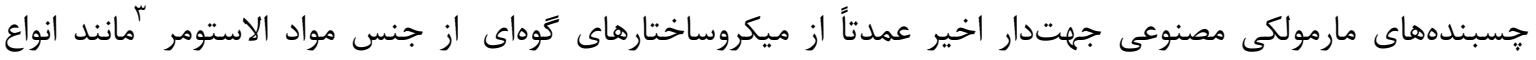

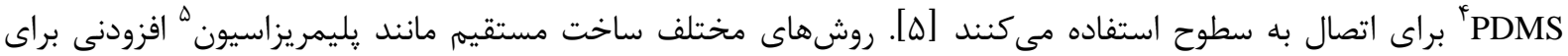

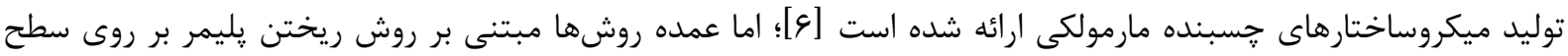

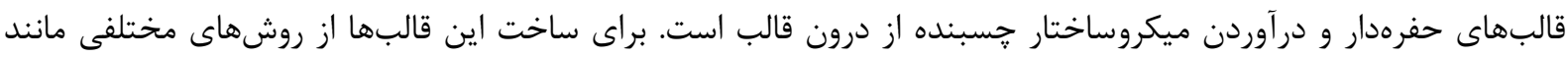

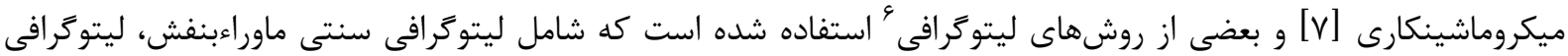

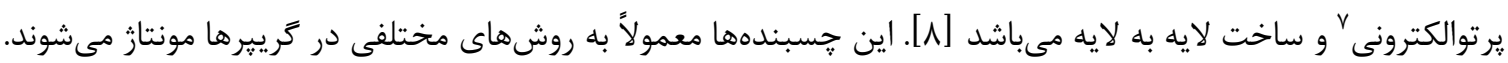

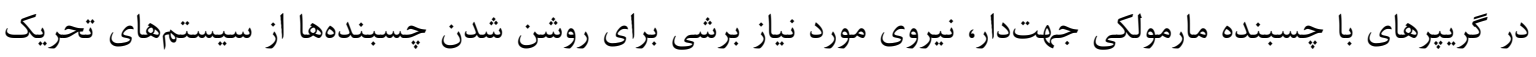

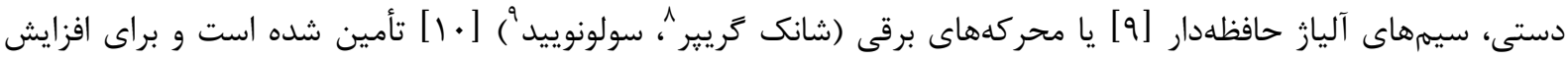

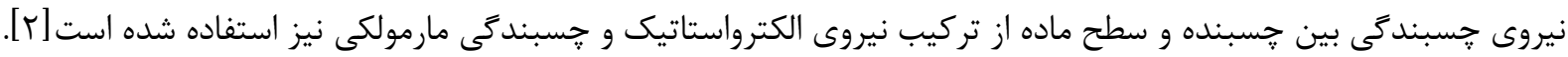

\footnotetext{
${ }^{1}$ Gripper

${ }^{2}$ Gecko-like microstructures

${ }^{3}$ Elastomer

${ }^{4}$ Polydimethylsiloxane

5 Polymerization

${ }^{6}$ Lithography

${ }^{7}$ E-beam

${ }^{8}$ Schunk gripper

${ }^{9}$ Solenoid
} 


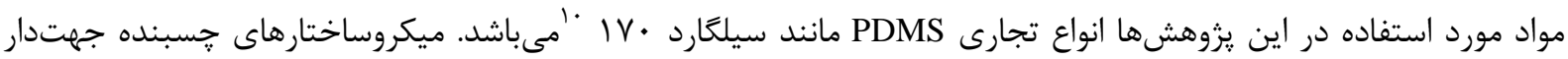

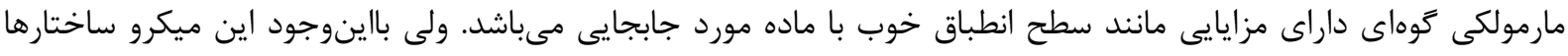

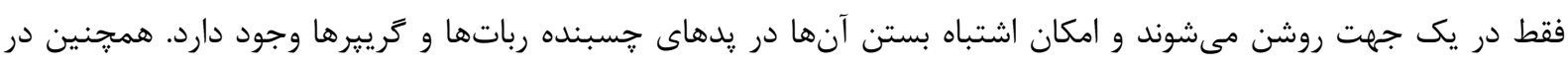

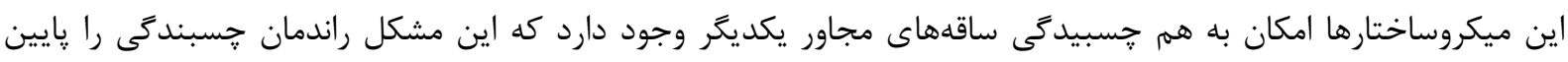
مى آورد.

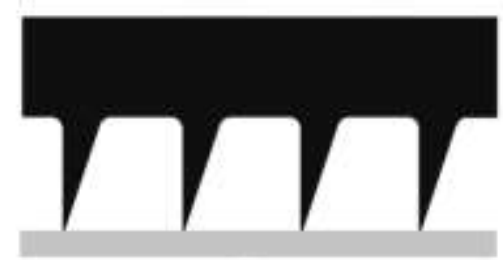

(N)

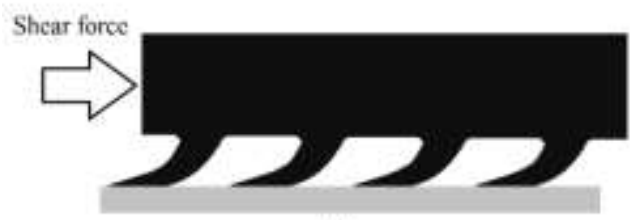

(H)

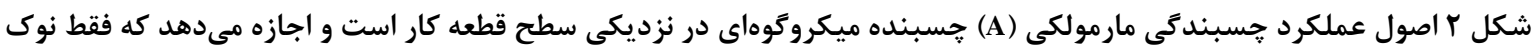

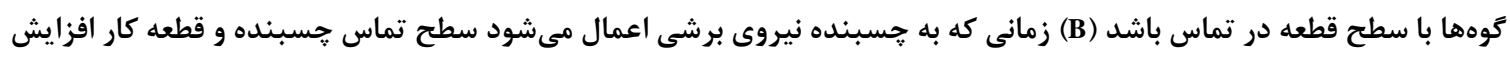

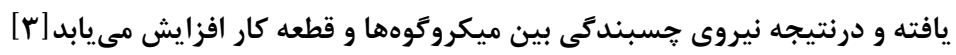

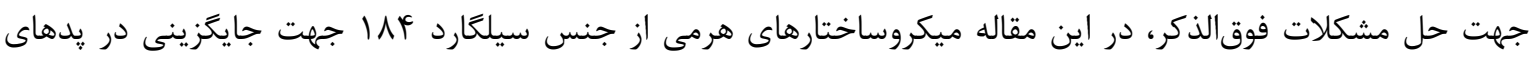

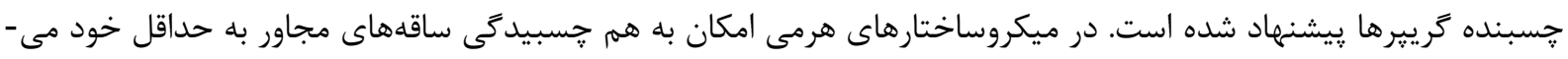

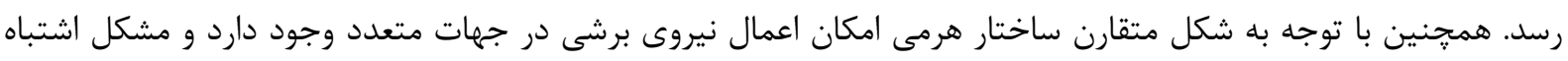

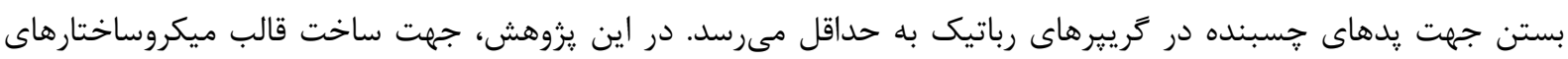

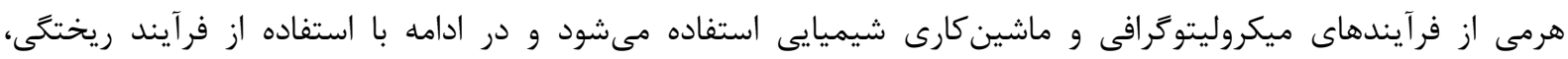
ميكروساختارهاى جسبنده هرمى توليد مى شوند.

r- مواد و فر آيندها

در اين بخش مواد مورد استفاده در فرآيند ساخت جسبنده هرمى مارمولكى و فرآيندهاى مورد استفاده جهت ساخت اين ميكروساختارها تشريح مى گردد.

\section{1-1- (- ميكروساختارهاى جسبنده هر مى}

با توجه به هزينههاى بالاى قالبسازى ميكروساختارهاى مارمولكى، تاكنون روابط تِئورى براى طراحى اين ميكروساختارها

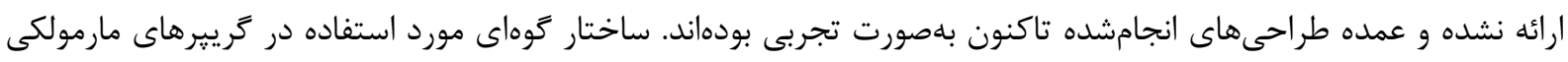

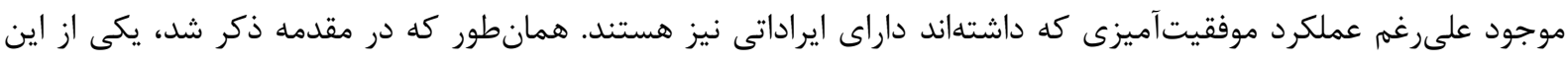

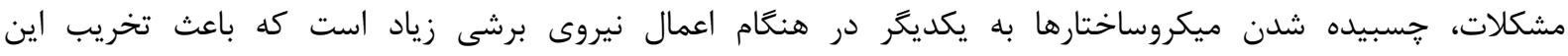

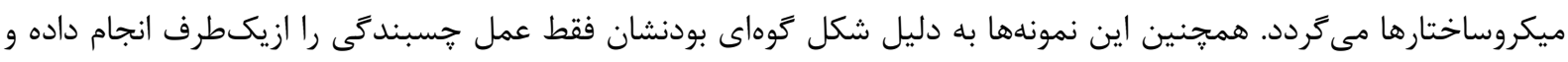

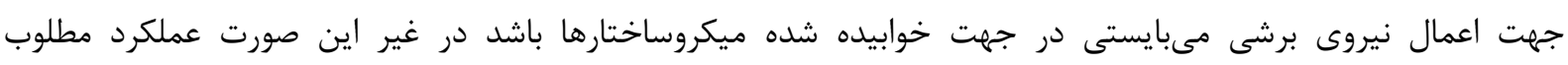
جسبندگى حاصل نمىشود.

يكى ديغر از معايب ميكروساختارهاى گوهاى شكل مورداستفاده، راندمان نسبتاً پايين آنهاست. اين ميكروساختارها در

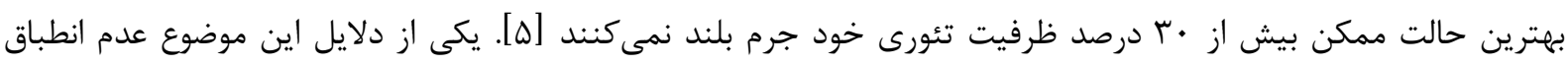


كامل سطح جسبنده با سطح ماده مورد جابجايى است. باوجوداينكه در گرييرهاى موجود با تركيب سطح صلب و انعطافيذير

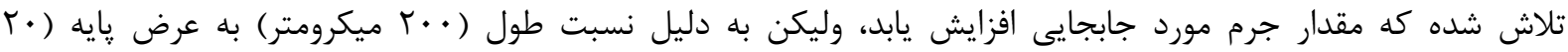

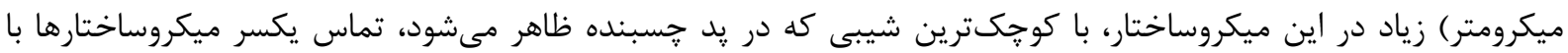

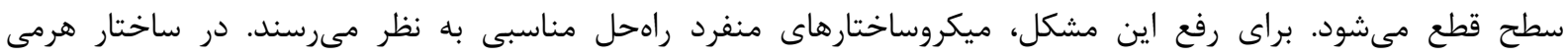
ييشنهادى علاوه بر مزيت انطباق بهتر با سطوح به دليل منفرد بودن ميكروساختارهاى جسبنده، احتمال جسبيده شدان

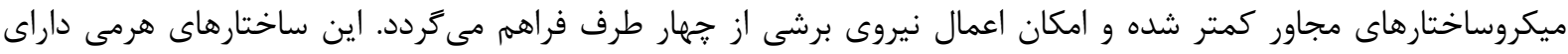

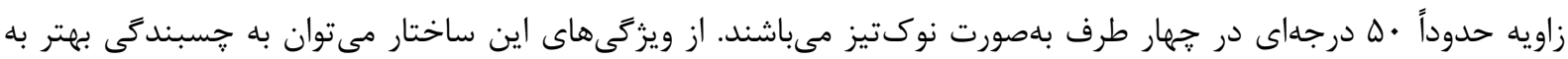

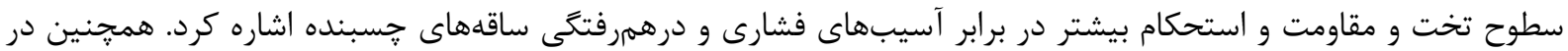
اين ساختار امكان اعمال نيروى برشى جهت دركير كردن جسبنده با سطوح از جهار طرف وجود داش داشته و امكان اشتباه بسته

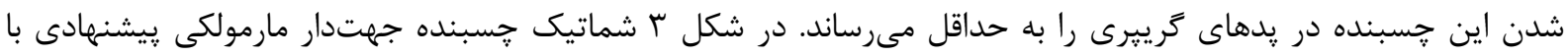

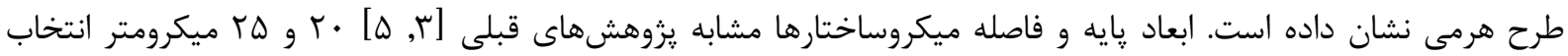

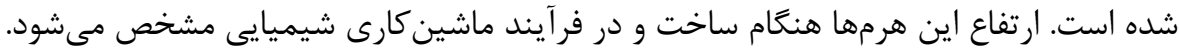

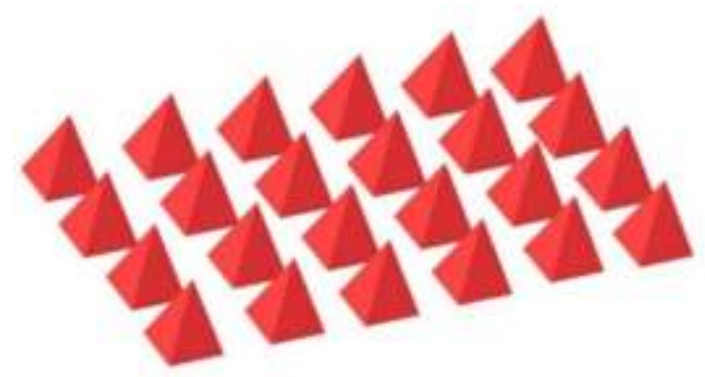

شكل ץ شماتيك جسبنده جهتدار مارمولكى پيشنهادى با طرح هر مى

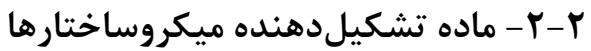

״ֶ به دليل نياز جسبندههاى مارمولكى به قابليت استفاده مجدد، براى ساخت آنها از مواد الاستومر حجمى استفاده

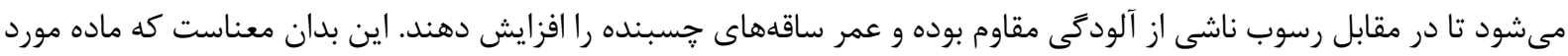

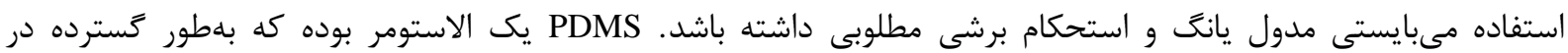

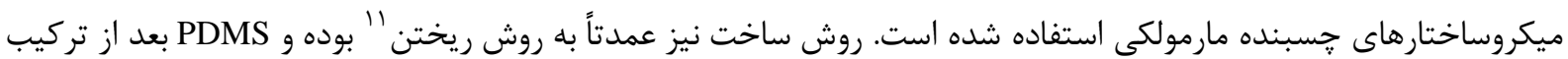

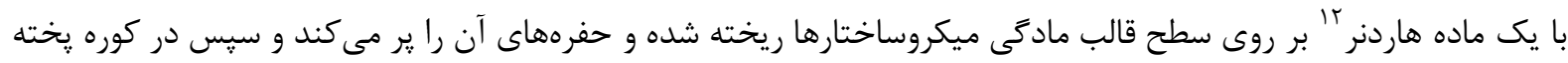

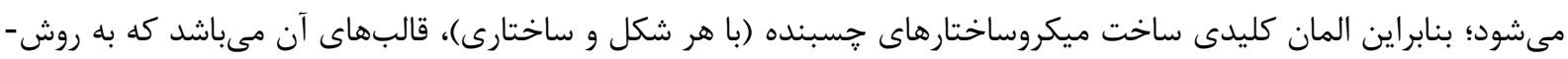

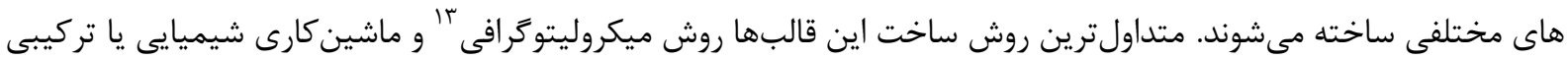
از اين دو است.

مقدار PDMS مايع به مقدار ضخامت جسبنده بستكى دارد. هرجقدر ميزان ضخامت بيشتر باشد استحكام جسبنده

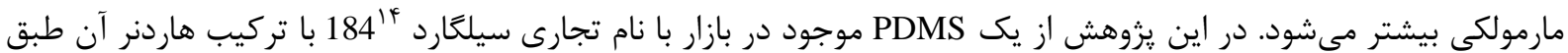

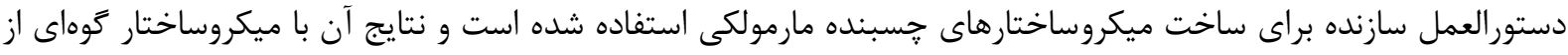
همين جنس مقايسه شده است.

\footnotetext{
${ }^{11}$ Casting

${ }^{12}$ Hardener

${ }^{13}$ Microlithography

${ }^{14}$ Sylgard- 184
} 


\section{r-r-r ساخت قالب ميكروساختارهاى جسبنده مارمولكى}

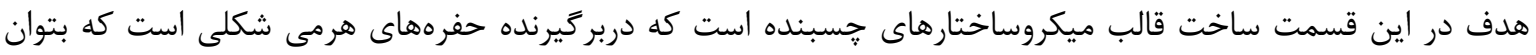

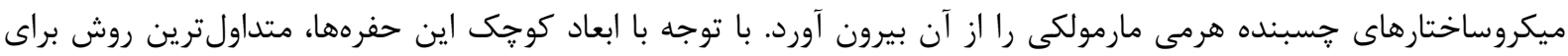

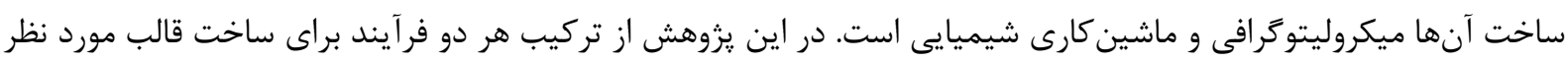

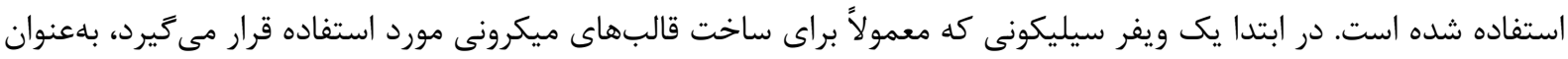

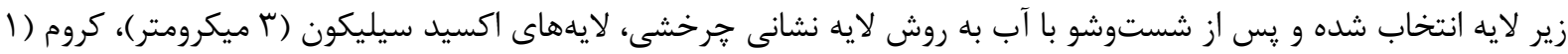

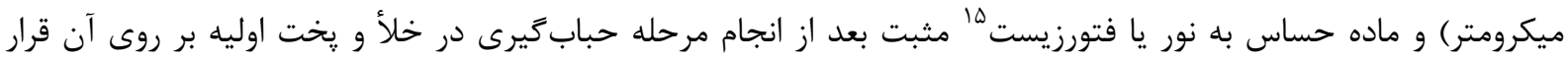

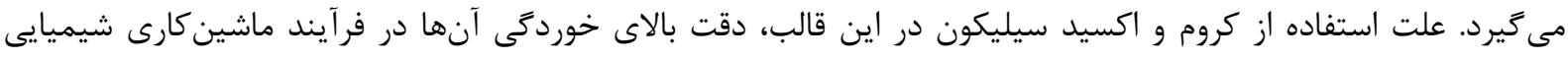

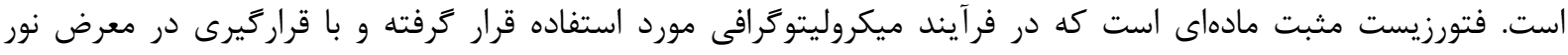

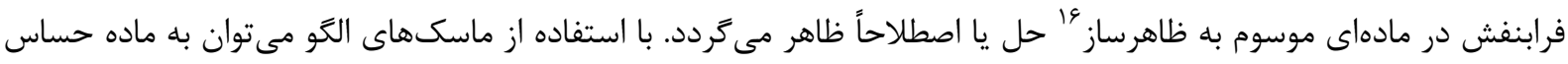

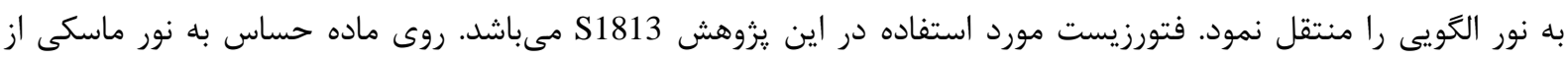

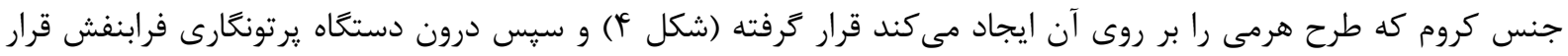

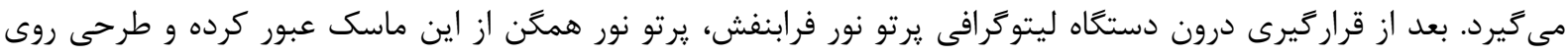

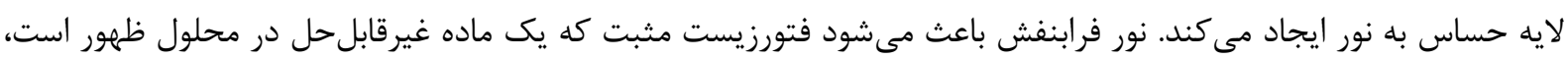

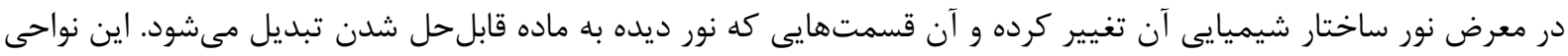

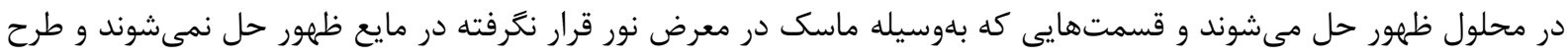

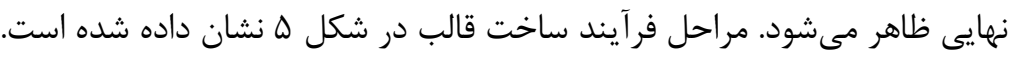

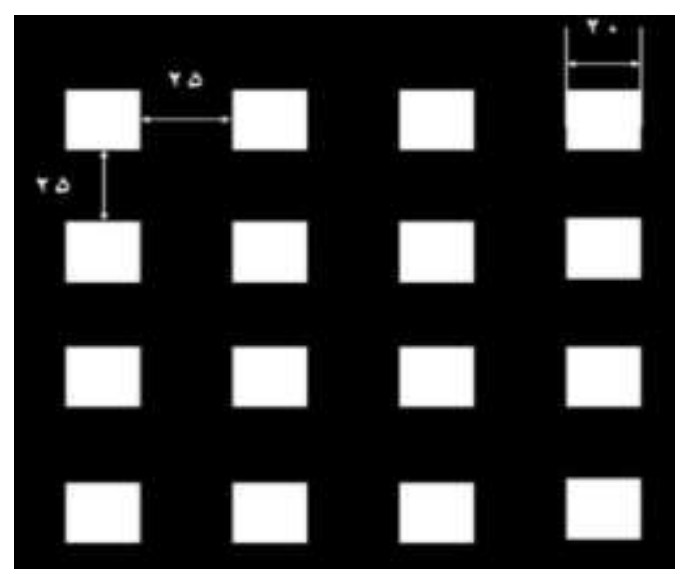

شكل F طرح ماسك فتورزيست مثبت براى جسبنده مارمولكى هر مى (همه ابعاد به ميكرومتر است)

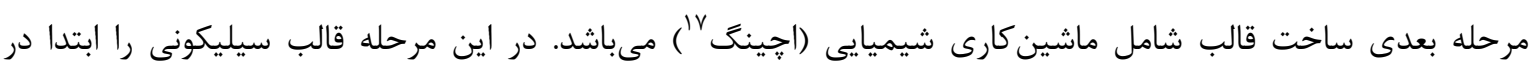

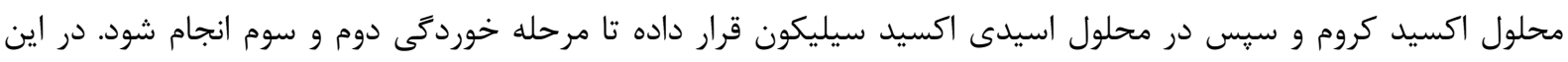

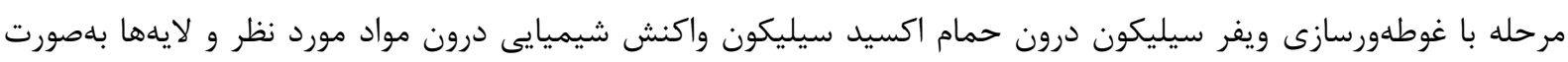

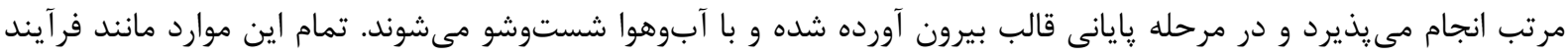

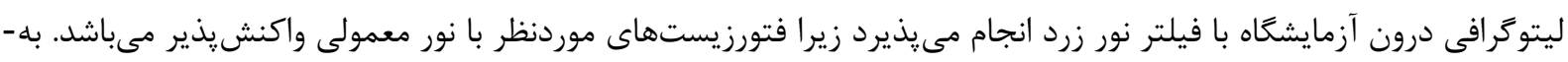

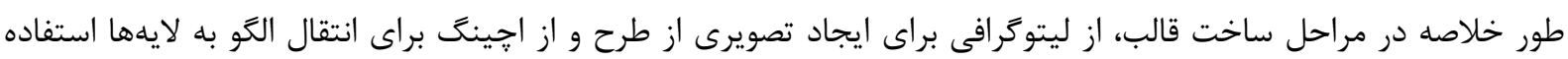

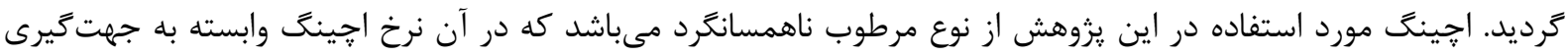

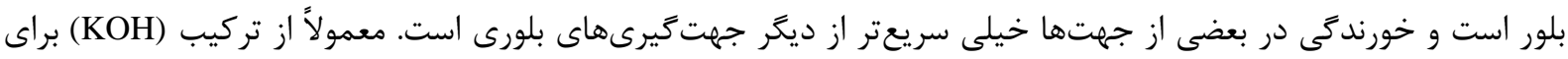

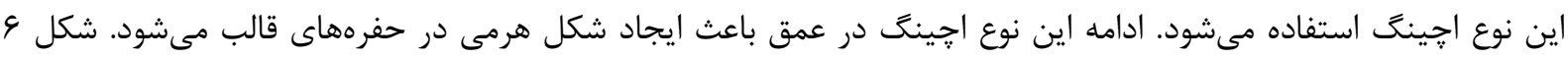

\footnotetext{
${ }^{15}$ Photoresist

${ }^{16}$ Developer

${ }^{17}$ Etching
} 


\section{سطح مقطع اين نوع إجينَ را نشان مىدهد.}

r-r-r

جهت ساخت ميكروساختارهاى هرمىشكل جسبنده، سيلعًارد 1NF مطابق دستورالعمل سازنده آماده شده و در محفظه

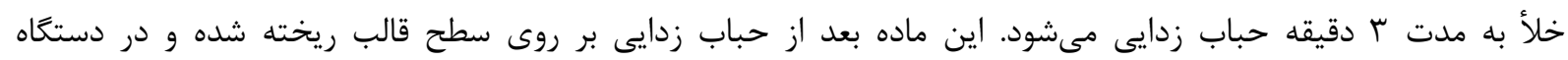

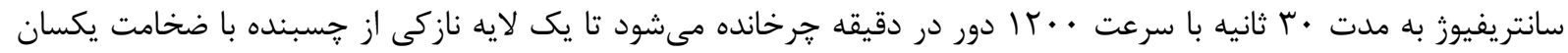

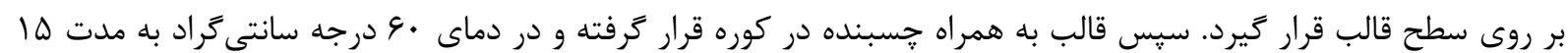

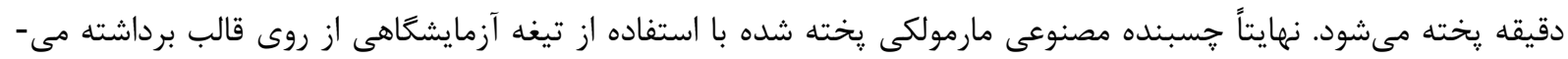

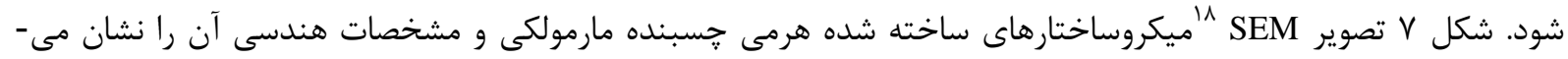

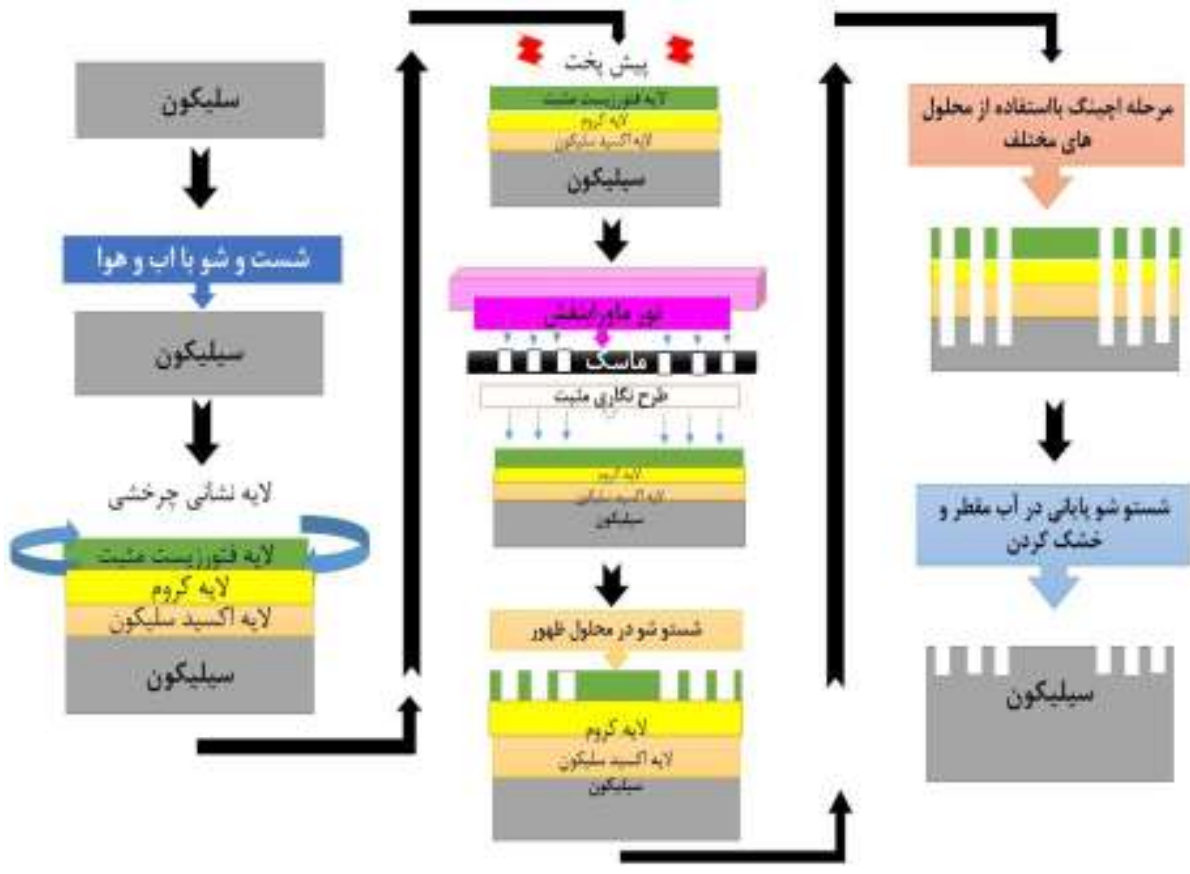

شكل ه مراحل ساخت قالب ميكرو ساختار جسبنده مارمولكى هرمى با استفاده از فرآيندهاى ميكروليتوكر افى و ماشينكارى شيميايى

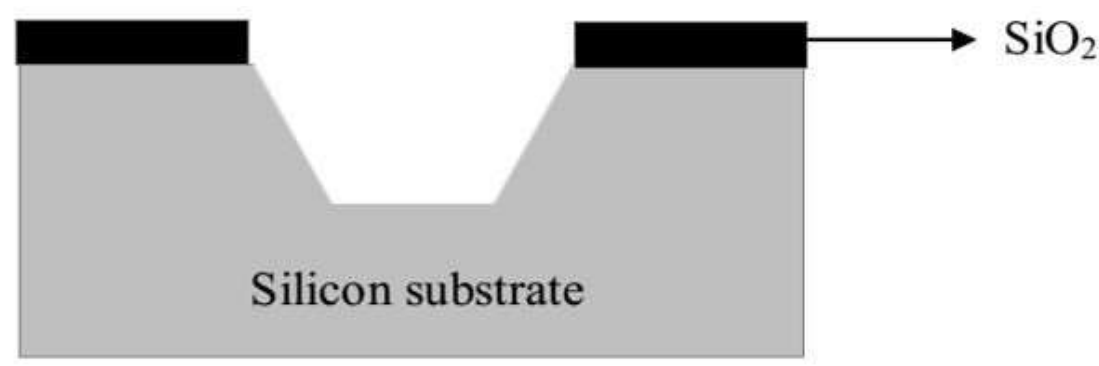

شكل 9 سطح مقطع إينغَ ناهمسانكَرد

\footnotetext{
${ }^{18}$ Scanning electron microscope
} 


\section{ب- آزمايشها}

يس از انجام مراحل ساخت قالب بهوسيله فرآيند ميكروليتوكرافى و ماشين كارى شيميايى، نمونه ساختهشده كه بهاعنوان

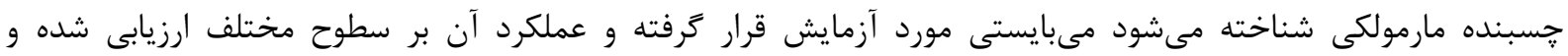

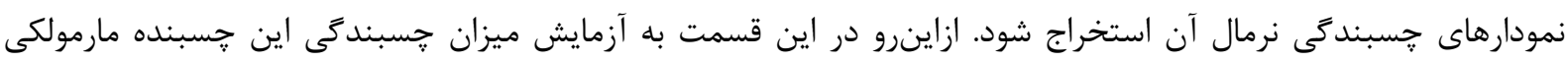

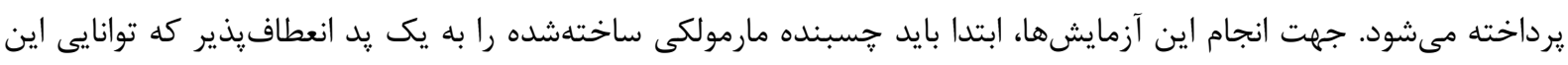

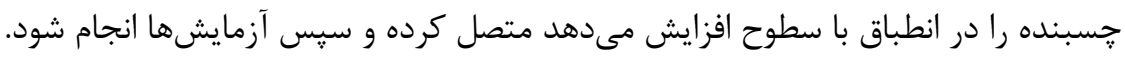

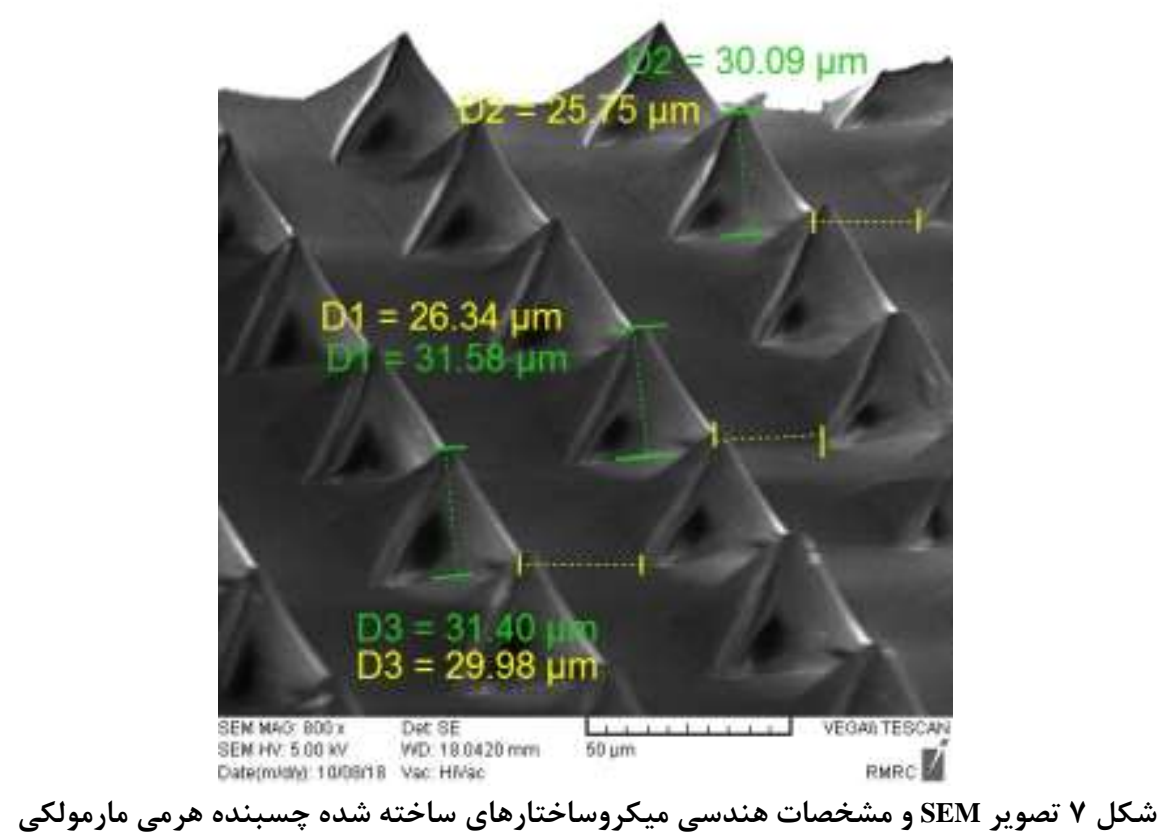

ץ-1- طراحى پِد جسبنده براى آزمايشها

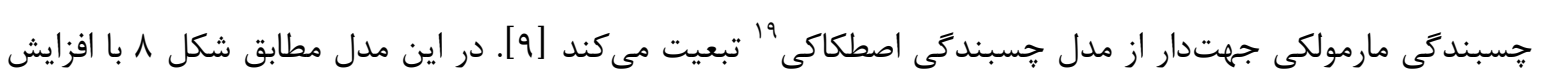

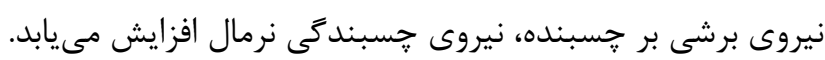

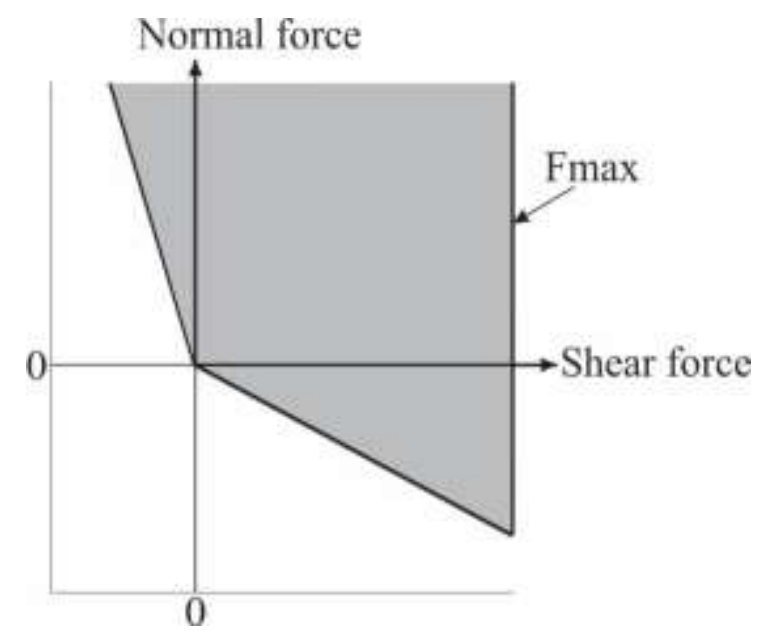

شكل 1 مدل جسبندكى اصطكاكى. مقادير زير صفر نيروى نرمال نشاندهنده هسبندكى هستند [9]

بنابراين براى ارزيابى عملكرد جسبنده ساختهشده نياز است كه ابتدا اين جسبنده بر روى سطح مورد نظر قرار كيرد، سيس

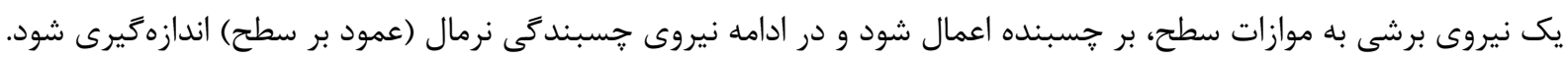

\footnotetext{
${ }^{19}$ Frictional adhesion
}

مكانيك مواد بِيشرفته و هوشمند/ سال ••f|f دوره / / شماره | 
اين مراحل را هم مىتوان در يك گريير (دستى يا اتومات) يا يك يد جسبنده بلهورت دستى انجام داد. جهت اندازميرى

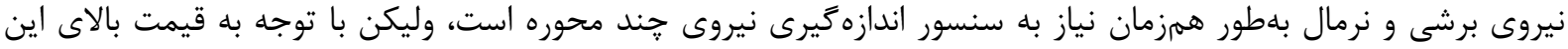

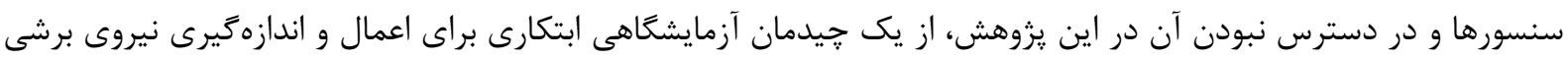

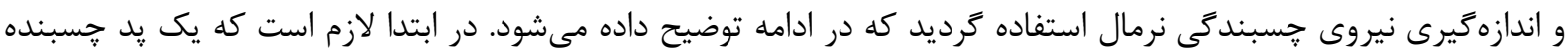

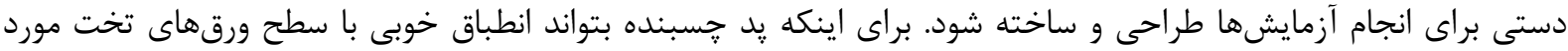

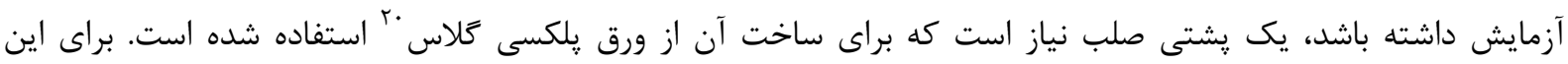

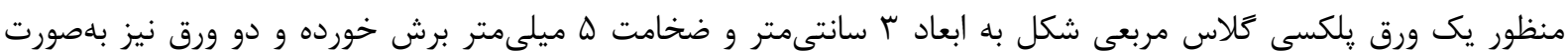

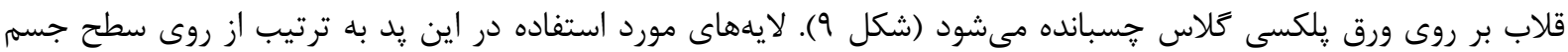

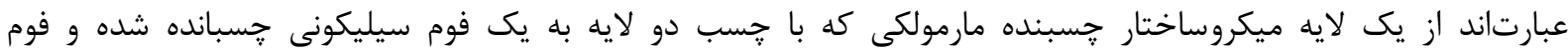

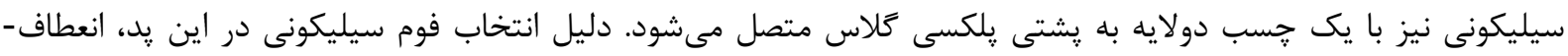

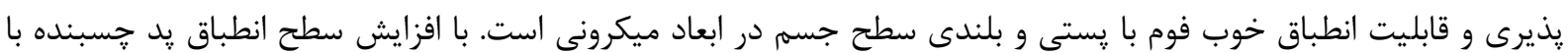

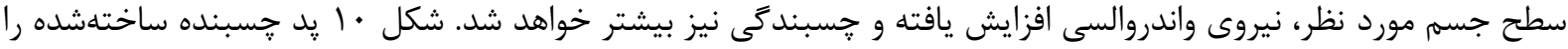

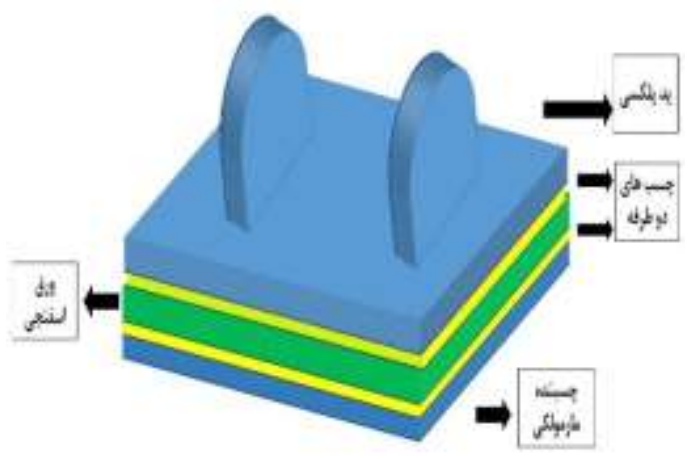

شكل 9 لايههاى پِ جسبنده مورداستفاده در آزمايشها

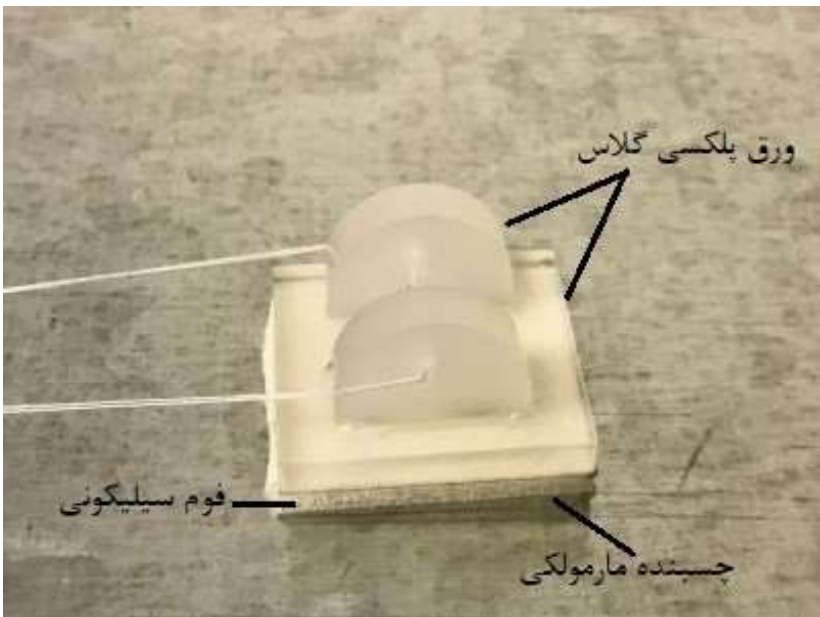

شكل •| (ֶ) جسبنده ساختهشده 


\section{r-r - r- مجموعه آزمايشغاهى و آزمايشها}

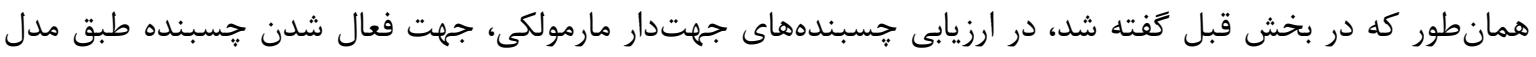

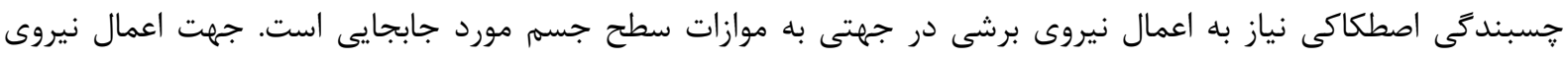

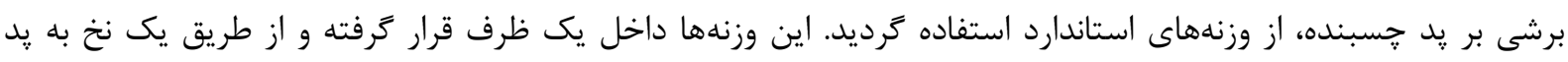

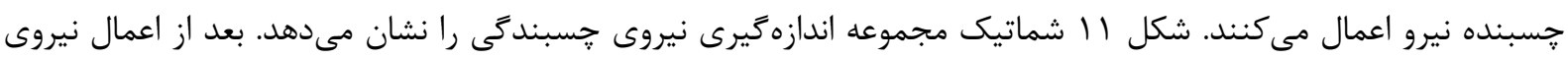

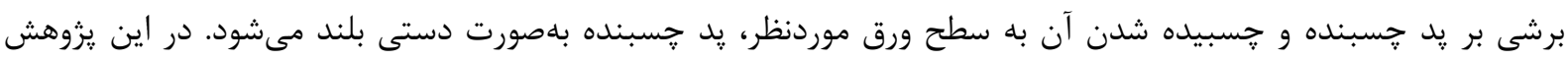

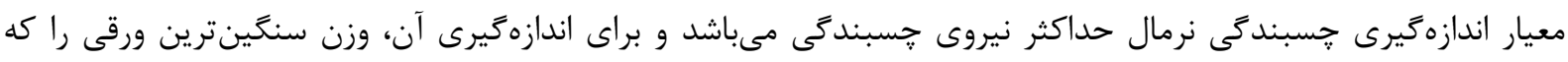

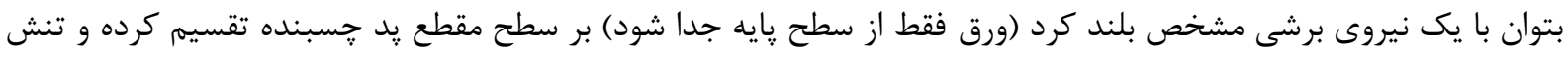

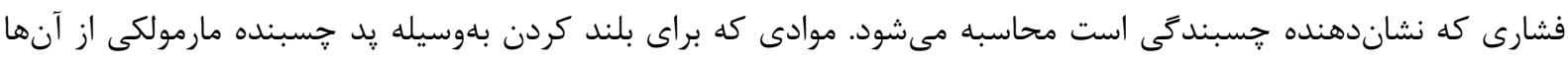

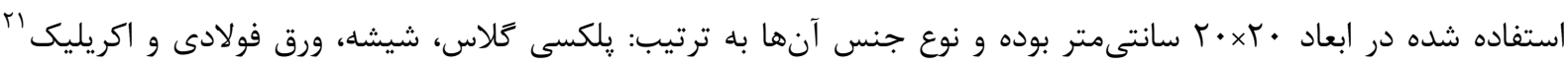

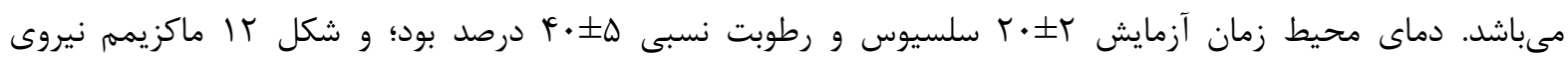

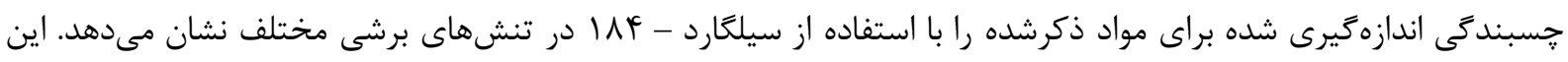

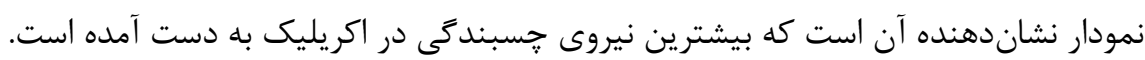

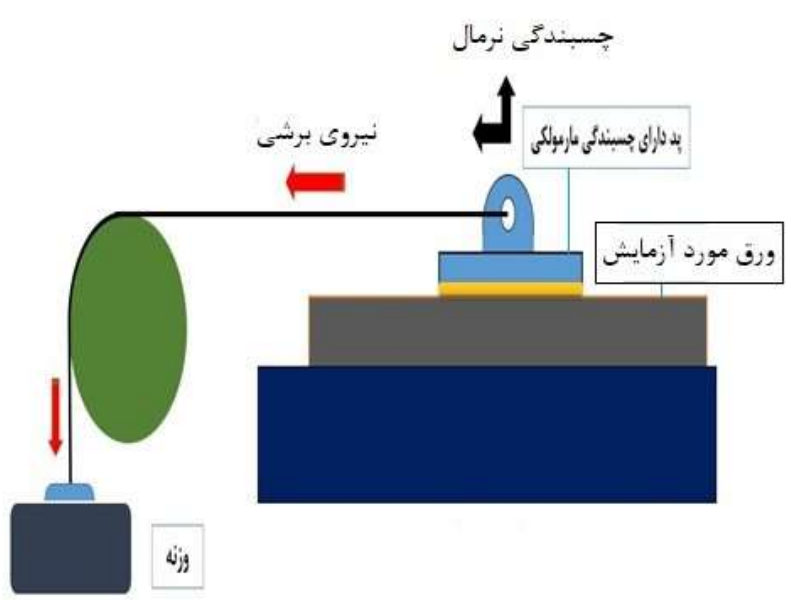

شكل Iا شماتيك مجموعه آزمايشَاهى اندازهخيرى

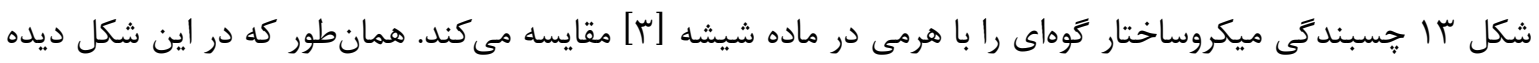

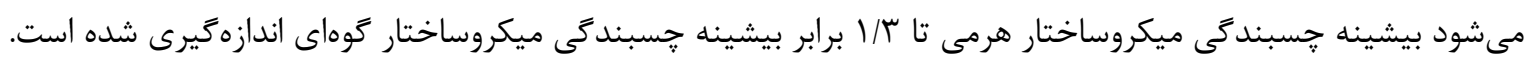

- +

در اين يزوهش، يك قالب جهت ساخت ميكروساختارهاى جسبنده مارمولكى هرمى شكل طراحى و ساخته شد كه عملكرد

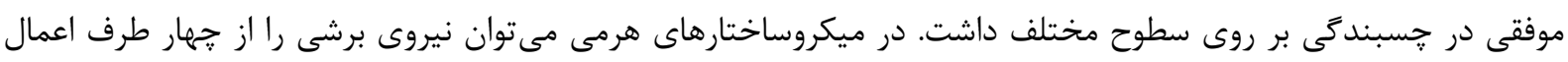

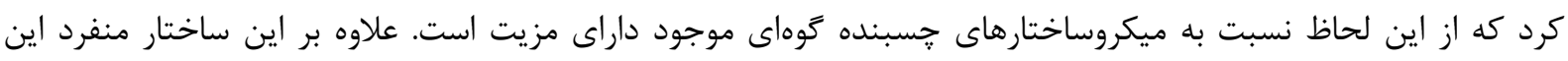

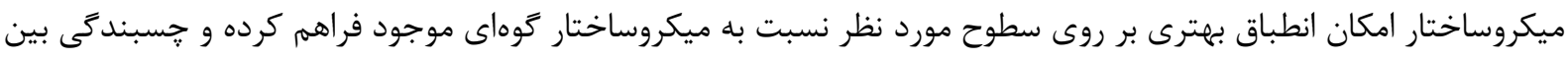

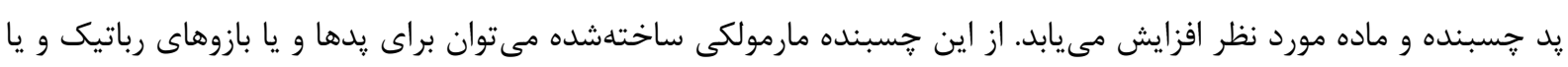
رباتهاى ديوار نورد استفاده كرد.

\footnotetext{
${ }^{21}$ Acrylic
} 


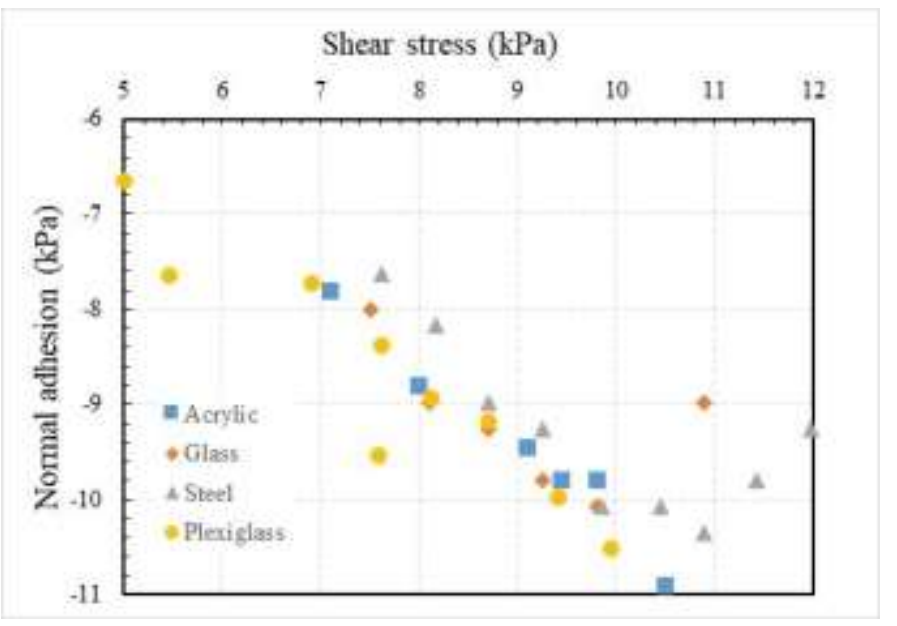

شكل rا ماكزيمم تنش برشى و حسبندكى نرمال اندازهكيرى شده در حسبنده مارمولكى هرمى بر روى مواد مختلف

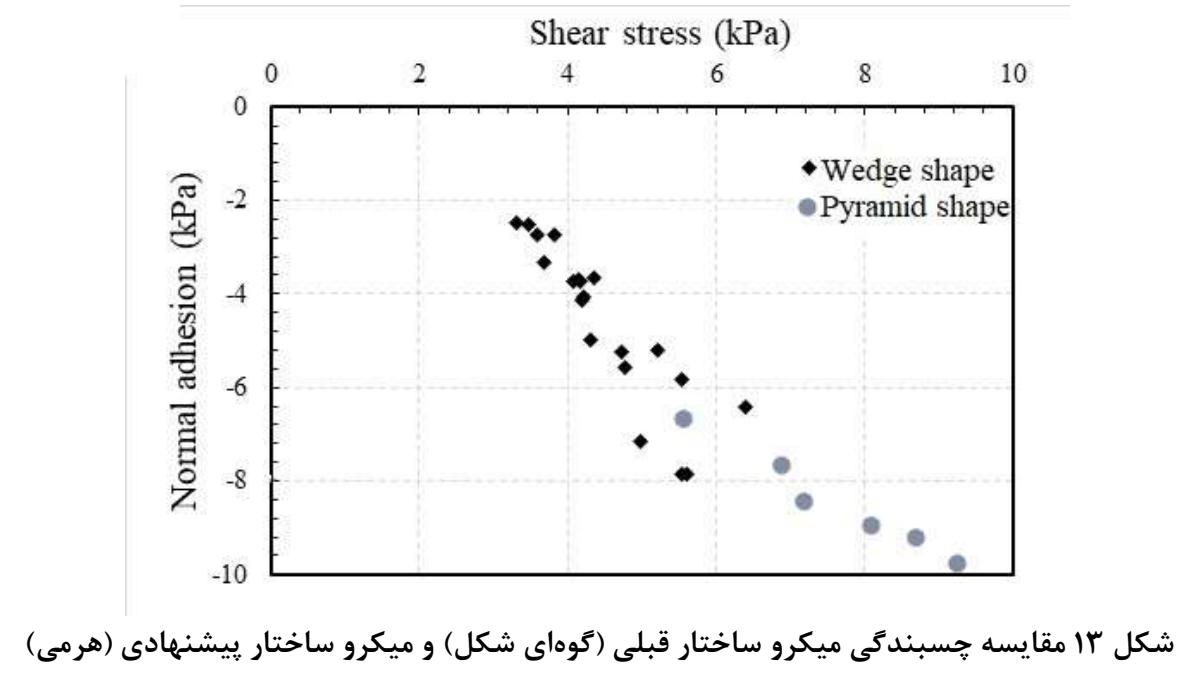

[1] Parness A, Kennedy B A, Heverly M C, Cutkosky M R, Hawkes E W. Grippers based on opposing van der waals adhesive pads. Google Patents; 2016.

[2] Dadkhah M, Zhao Z, Wettels N, Spenko M. A self-aligning gripper using an electrostatic/gecko-like adhesive. in International Conference on Intelligent Robots and Systems (IROS). 2016;1006-1011.

[3] Modabberifar M, Spenko M. Development of a gecko-like robotic gripper using scott-russell mechanisms. Robotica. 2020;38:541-549.

[4] Santos D, Spenko M, Parness A, Kim S, Cutkosky M. Directional adhesion for climbing: theoretical and practical considerations. Journal of Adhesion Science and Technology. 2007;21:1317-1341.

[5] Parness A, Soto D, Esparza N, Gravish N, Wilkinson M, Autumn K, Cutkosky M. A microfabricated wedgeshaped adhesive array displaying gecko-like dynamic adhesion, directionality and long lifetime. Journal of the Royal Society Interface. 2009;6:1223-1232.

[6] Davoudinejad A, Ribo M M, Pedersen D B, Islam A, Tosello G. Direct fabrication of bio-inspired gecko-like geometries with vat polymerization additive manufacturing method. Journal of Micromechanics and Microengineering. 2018;28:085009.

[7] Day P, Eason E V, Esparza N, Christensen D, Cutkosky M. Microwedge machining for the manufacture of directional dry adhesives. Journal of Micro and Nano-Manufacturing. 2013;1:011001. 
[8] Geim A K, Dubonos S V, Grigorieva I V, Novoselov K S, Zhukov A A, Shapoval S Y. Microfabricated adhesive mimicking gecko foot-hair. Nature materials. 2003;2:461-463.

[9] Modabberifar M, Spenko M. A shape memory alloy-actuated gecko-inspired robotic gripper. Sensors and Actuators A: Physical. 2018;276:76-82.

[10] Hosein Mirzaee R, Modabberifar M. A solenoid actuated gecko-like robotic gripper. Iranian Journal of Manufacturing Engineering. 2019;6:43-50. 